Revue belge de géographie

\title{
Contemporary Danish landscape research
}

Etat de la recherche paysagère au Danemark

\section{Henrik Vejre and Jesper Brandt}

\section{(2) OpenEdition}

\section{Journals}

\section{Electronic version}

URL: http://journals.openedition.org/belgeo/13532

DOI: 10.4000/belgeo.13532

ISSN: 2294-9135

\section{Publisher:}

National Committee of Geography of Belgium, Société Royale Belge de Géographie

\section{Printed version}

Date of publication: 30 September 2004

Number of pages: 223-230

ISSN: 1377-2368

\section{Electronic reference}

Henrik Vejre and Jesper Brandt, « Contemporary Danish landscape research », Belgeo [Online], 2-3 |

2004, Online since 14 September 2013, connection on 08 July 2020. URL : http://

journals.openedition.org/belgeo/13532; DOI : https://doi.org/10.4000/belgeo.13532

This text was automatically generated on 8 July 2020 .

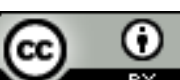

Belgeo est mis à disposition selon les termes de la licence Creative Commons Attribution 4.0 International. 


\title{
Contemporary Danish landscape research
}

\author{
Etat de la recherche paysagère au Danemark
}

Henrik Vejre and Jesper Brandt

\section{Introduction}

1 Decades of studies within the "mother sciences" of landscape research, e.g. geology, geography, biology, and spatial planning nourished modern landscape research of Denmark, which mainly deals with rural geography, agricultural landscapes and landscape ecology. The Department of Geography at the University of Copenhagen has been a centre for landscape related research, and in the 1970s the transdisciplinary Roskilde University combined biology and geography in a dynamic environment, rooting landscape ecology in Denmark. Studies of structure and dynamics of small uncultivated areas in agricultural landscapes were done in island-bio-geographical and socio-economic contexts (Agger \& Brandt, 1988). Danish landscape ecology was thereby linked to a mainstream trend within international landscape ecology. In the 1990s, spatial planning, landscape architecture and countryside management at the Royal Veterinary and Agricultural University merged to form the research area landscape management. Further, the departments of Botany and Cultural Geography of the University of Copenhagen developed issues within landscape ecology. The Forest and Landscape Research Centre, National Environmental Research Institute and Danish Institute of Agricultural Sciences have all put considerable emphasis on subjects as dispersal ecological aspects of the landscape and the farmers role in managing the landscape.

\section{Contemporary landscape research in Denmark}

During the last decade, research has been done within numerous aspects of landscape science. This paper only presents major assets, and put emphasis on the themes 
covered by the last 10 years concerted efforts within landscape research. These efforts comprised mainly five inter- and transdisciplinary programmes ${ }^{1}$.

In the following the main themes covered by the programmes are presented.

4 All programmes required participitation of different institutions (listed in Table 1) and several projects implied interdisciplinarity with researchers participating from arts, science and social sciences. In many projects the work was done on information tied to a specific place or region, sharing common databases.

Table 1. Primary actors in Danish landscape research (listed alphabetically).

\begin{tabular}{|c|c|}
\hline Institution & Fields of research \\
\hline $\begin{array}{l}\text { Aalborg University, Dept of development and } \\
\text { planning. } \\
\text { www.plan.aau.dk }\end{array}$ & $\begin{array}{l}\text { Public authorities, planning control, and } \\
\text { land-use laws. Cadastral and Land } \\
\text { Registration within Land Management } \\
\text { Valuation and compensation. } \\
\text { Digital geoinformation and physical } \\
\text { planning, land use and land management. }\end{array}$ \\
\hline $\begin{array}{l}\text { Danish Centre for Forest, Landscape } \\
\text { and Planning Royal Veterinary and } \\
\text { Agricultural University } \\
\text { www.sl.kvl.dk }\end{array}$ & $\begin{array}{l}\text { Agricultural policies and landscape } \\
\text { development } \\
\text { Planning and management for } \\
\text { multifunctional landscapes } \\
\text { Public participation in the planning } \\
\text { process } \\
\text { Landscape management in the urban fringe } \\
\text { The farmer as landscape manager }\end{array}$ \\
\hline $\begin{array}{l}\text { Danish Institute of Agricultural Sciences, Tjele, Dept } \\
\text { of Agroecology } \\
\text { www.agrsci.dk }\end{array}$ & $\begin{array}{l}\text { Development of a basis for sustainable } \\
\text { agriculture in } \\
\text { relation to production, environment, } \\
\text { nature and landscape } \\
\text { at all levels from field via farm to regional } \\
\text { and international level }\end{array}$ \\
\hline $\begin{array}{l}\text { Geological Survey of Denmark and Greenland. } \\
\text { www.geus.dk }\end{array}$ & $\begin{array}{l}\text { Late-Pleistocene and Holocene climatic } \\
\text { change at the north Atlantic margin } \\
\text { Quantitative palaeoecology } \\
\text { Landscape development } \\
\text { Vegetation history } \\
\text { Human impact and natural forest } \\
\text { dynamics. }\end{array}$ \\
\hline $\begin{array}{l}\text { National Environment Research Institute, Denmark. } \\
\text { Dept of terrestrial ecology } \\
\text { www.dmu.dk }\end{array}$ & $\begin{array}{l}\text { Conditions for plants and animals in the } \\
\text { cultural landscape } \\
\text { Nature quality - concepts and methods for } \\
\text { management } \\
\text { Population and vegetation ecology - from } \\
\text { genetic analysis to landscape models }\end{array}$ \\
\hline
\end{tabular}




\begin{tabular}{|l|l|}
\hline $\begin{array}{l}\text { Roskilde University, Dept of Geography and } \\
\text { International Development Studies, Dept of } \\
\text { Environment, Technology and Social Studies } \\
\text { www.ruc.dk }\end{array}$ & $\begin{array}{l}\text { Monitoring small biotopes, heterogeneity } \\
\text { and urbanization of agricultural } \\
\text { landscapes. } \\
\text { Landscape aspects of organic farming. } \\
\text { Landscape conditions for past and present } \\
\text { land use in the Faroes and Greenland. }\end{array}$ \\
\hline $\begin{array}{l}\text { University of Copenhagen } \\
\text { Department of Geography } \\
\text { www.geogr.ku.dk }\end{array}$ & $\begin{array}{l}\text { Landscape studies in cultural, economic } \\
\text { and biophysical context } \\
\text { Land use analyses and landscape } \\
\text { characterization } \\
\text { Interaction between agricultural systems } \\
\text { and landscapes } \\
\text { Landscape changes and spatial diversity of } \\
\text { land use and landscape dynamics. }\end{array}$ \\
\hline $\begin{array}{l}\text { University of Southern Denmark } \\
\text { www.humaniora.sdu.dk }\end{array}$ & \begin{tabular}{l} 
Landscape history \\
\hline
\end{tabular}
\end{tabular}

5 The projects exploited the multidisciplinary character of landscapes, by developing methods, strategies, and routines for interdisciplinary cooperation and by encouraging interdisciplinary dialogue. All programmes were based on the recognition that economic, social and environmental problems are closely related to structure, function, valuation and development of the landscape. The projects have demonstrated that interdisciplinary research is indeed a challenging endeavor which in order to be successful, requires general knowledge as to concepts, theories, paradigms, terminology, and methods of disciplines different from one's own.

In the following the main themes covered by the programmes are presented.

\section{Landscape change}

$7 \quad$ Landscape history was scrutinized in case areas shared by many of the participating scientists, covering the whole time range from the Iron age to the post war period. The interaction between man and landscape has been a major issue, with emphasis on the cultural historical and nature conservation interests in relation to human economic and recreational use of the landscape. Land-use history in relation to plant diversity has been treated involving numerous disciplines. Several project used scenario studies to discuss and evaluate the future landscape development.

\section{Landscape and biological diversity}

8 Landscape structures were analyzed to obtain a thorough understanding of landscape entities, cultural circumstances and natural processes influencing the landscape structures, the regulation of ecosystems and the biological diversity. The elucidation of factors which influence present plant diversity in natural habitats subjected to human exploitation has been a major issue. The impact on species diversity of local environmental conditions and historical processes was analyzed aimed at investigating the conditions for the present biodiversity at the genetic, species, and ecosystem level. 
An important activity has been a discussion of the contents and function of the biodiversity concept in various scientific disciplines, as well as assessing its value as a quantitative and qualitative measurement tool.

\section{Nature quality and landscape management}

The theme encompassed the study of nature quality in ecosystems in cultural landscapes. Landscape management was treated from several different angles, along with the theoretical basis for elaboration of strategies for landscape management and protection of biodiversity at different levels. Legal aspects, economic incentives and farmer's production of nature qualities, design and implementation processes in the countryside with emphasis on the role of planning, land use and structure changes in the landscape was treated. Scenario studies were used to study interactions between land management, agriculture, nature and environment in the countryside.

\section{Management and use of the countryside}

Several scientific disciplines dealt with values, consequences and planning in regard to integrated management and use of the countryside. A focal point was ethical weighing of values and interests, e.g. values and view of nature among inhabitants of suburbs, and the social dimension of outdoor recreation. Scenarios were used to test visions on multiple use of the countryside. Part of the theme dealt with the agrarian landscape, including tourism and recreation in the agrarian landscape, farm buildings and landscape, state of conservation of archaeological remains on arable land, quantitative estimates, regionalism and causes behind property changes in the agrarian landscape. Finally a collection of tools was developed for analysis concerning nature, management and regulation, such as measures of landscape diversity and biodiversity, conditions and means for regulation, ways of public management and handling of interest groups.

Table 2. Development of the Danish landscape.

\begin{tabular}{|l|l|}
\hline Pre-history & $\begin{array}{l}\text { Codevelopment of human settlement and vegetation. Development of farmed } \\
\text { landscape in the Neolithic. During bronze and iron ages the landscape got } \\
\text { completely influenced by human activity. Semi-permanent settlement } \\
\text { structure. }\end{array}$ \\
\hline $700-1800$ & $\begin{array}{l}\text { Villages located at fixed sites. Farming in a centre-periphery model with } \\
\text { arable fields close to the village and commons at the edges of the village } \\
\text { domain. Strong fragmentation of fields. Extensive use of Calluna heath land. } \\
\text { Grazing in flood plains. }\end{array}$ \\
\hline $1770-1850$ & $\begin{array}{l}\text { Complete transformation of eastern Denmark. Enclosure implied contiguous } \\
\text { gathering of fields belonging to one property. Elimination of commons, } \\
\text { Enclosure } \\
\text { farmage of wetlands. Dissolution of village structures and displacement of } \\
\text { tree production. Stone and earth walls were constructed between farms } \\
\text { properties and around forests. Planting of trees around farms and in field } \\
\text { margins. Landscape dominated by linear elements, and increasingly by } \\
\text { buildings. }\end{array}$ \\
\hline
\end{tabular}




\begin{tabular}{|l|l|}
\hline $\begin{array}{l}\text { 1850-1950 } \\
\text { Intensification }\end{array}$ & $\begin{array}{l}\text { Ditching of wet meadows, cultivation and afforestation of heath land, } \\
\text { drainage of upland soils with infiltration problems, deepening and } \\
\text { chanalization of streams and brooks. }\end{array}$ \\
\hline $\begin{array}{l}\text { Industrialization of } \\
\text { agriculture }\end{array}$ & $\begin{array}{l}\text { Urbanization of urban fringes. Conversion of ditched meadows to arable fields } \\
\text { in rotation. Elimination of earth and stone walls, hedgerows, water ponds and } \\
\text { other small biotopes. }\end{array}$ \\
\hline $1990-$ & $\begin{array}{l}\text { Restoration of streams, and water bodies, afforestation, planting of } \\
\text { hedgerows. Further industrialization of agriculture results in mega-fields and } \\
\text { huge emissions of nitrogen which eutrophiate terrestrial and aquatic } \\
\text { ecosystems. Continued urbanization of the urban fringe. }\end{array}$ \\
\hline
\end{tabular}

\section{Important landscape values of Denmark}

11 Denmark is an intensively farmed, and in places strongly urbanized country. With more than $7500 \mathrm{~km}$ coastline and $43,000 \mathrm{~km}^{2}$ of land territory, the coast is omnipresent and possesses major landscape and nature values, reflected in the EU Habitat designations of which more than $50 \%$ is related to marine and coastal environments including salt marshes, salt meadows, dunes, and brackish lagoons. The coastal landscapes are of strong international importance, not least due to their significance for migrating birds. The west Baltic Archipelagos is a partly submerged moraine landscape, which is unique and well preserved, containing a rich variation of coastal morphology. Special interest pertains to the largest raised peat bogs of continental Europe. The valley landscape of central Jutland, with its plateaus, deeply dissected valleys, partly occupied by lakes, has a strong regional importance in the north European lowland. Apart from these landscapes, the general agricultural landscapes house a rich variation of cultural landscapes of significance to wildlife and vegetation dependent on agricultural management, not least the extensively managed pastures.

\section{Major potentials of the Danish landscape}

The primary means of enhancing natural values in the Danish landscapes is to restore the natural vegetation (mainly decidous forests) and to restore the natural hydrological regime. At present, afforestation are taking place with approximately 1000 ha per year, and numerous wetland restoration projects are carried out, the largest one restoring the lowest $20 \mathrm{~km}$ of the largest Danish watercourse after having been chanalized in 40 years.

\section{Major threats to the Danish landscape}

The primary threats pertain to industrialization of agriculture, and urbanization. In particular the air- and water borne emission of $\mathrm{N}$ compounds is a constant nuisance to the seminatural areas as forests, heath land, commons and meadows. But whereas technical and management solutions seem within reach here, the urbanization and intensification of infrastructure are apparently harder to handle. 


\section{BIBLIOGRAPHY}

AGGER P. (1995), "Nordic Countries: Scenario studies and nature development policies", in SCHOUTE J.F. Th. et al., Scenario studies for the rural environment, Kluwer Academic Publishers, Dordrecht, pp. 525-537

AGGER P. \& BRANDT J. (1999), "Strategies concerning ecological networks in Denmark - a review" , in MIKLÓS L. (Ed.) (1999), Cultural Landscapes for Ecological Networks, Foundation UNESCO-Chair for ecological awareness, Banská Stiavnica, Slovak Republic, $100 \mathrm{p}$.

ANKER H.T. (1997), "Biodiversity and the Importance of the Legal Framework”, in ARLER F. \& SVENNEVIG I. (eds.), Cross-cultural Protection of Nature and the Environment, Odense University Press, pp. 93-103.

ARLER F. \& SVENNEVIG I. (1997) "Studying Biodiversity and Culture in Relation to Decision Making”, in UNEP, Biodiversity - cultural and ethical aspects

BRANDT J. (1995), “Ecological networks in Denmark”, in VAN BUUREN M. \& JONGMAN R. (eds.), Ecological networks in Europe, Special issue of the journal "Landschap", Wageningen, pp. 63-76.

BRANDT J. (1999), “Geography as 'landscape ecology”, Danish Journal of Geography, 1 (Special Issue), pp. 21-32.

BRANDT J., PRIMDAHL J. \& REENBERG A. (1999), "Rural Land-Use and Landscape Dynamics Analysis of 'Driving Forces' in Space and Time”, in KRÖNERT R., BAUDY J., BOWLER I.R. \& REENBERG A., Land-Use Changes and their Environmental Impact in Rural Areas in Europe, edited by The Parthenon Publishing Group, pp. 81-102.

BRANDT J., BUNCE R. G. H. , HOWARD D.C. \& PETIT S. (2002), “General principles of monitoring land cover change based on two case studies in Britain and Denmark", Landscape and Urban Planning, 935, pp. 1-15.

BRANDT J. \& VEJRE H. (2004), "Multifunctional landscapes - motives, concepts and perceptions", in BRANDTJ. \& VEJRE H. (eds.), Multifunctional landscapes, vol. 1, Theory, values and history, Witpress, pp. 3-31.

CASPERSEN O.H. \& STENSTRUP J. (1998), "GIS-based methods for rural land use analysis based on the integrated agricultural control systems IACS", International Institute for Aerospace survey and earth sciences Journal, 1997(3).

FRITZBØGER B. (1999), “Forest legislation and management in Scandinavia c. 1660-1850: Natural resources between market economy and conservation”, Jahrbuch für europäische Verwaltungs geschichte, 11 .

HÖLL A. \& MøRCH H. (Eds.) (2002), “Landscape change and scenario studies”, Danish Journal of Geography, 3 (special issue).

KRISTENSEN S.P. (2003), "Multivariate analysis of landscape changes and farm characteristics in a study area in central Jutland, Denmark”, Ecological modelling, 168, 3, pp. 303-318.

KRISTENSEN S.P., THENAIL C. \& KRISTENSEN L. (2001), “Farmers' involvement in landscape activities: An analysis of the relationship between farm location, farm characteristics and landscape changes in two study areas in Jutland, Denmark", Journal of Environmental Management, 61, pp. 301-318. 
KRISTENSEN S. P. \& CASPERSEN O.H. (2002), “Analysis of changes in a hedgerow network landscape in central Jutland, Denmark”, Journal of Environ mental Management, 66, 2, pp. 171-183.

KRISTENSEN L. S., THENAIL C. \& KRISTENSEN S.P. (2004), "Landscape changes in agrarian landscapes in the 1990s: the interaction between farmers and the farmed landscape.A case study from Jutland, Denmark", Journal of Environmental Management, 71, 3, pp. 231-244.

NIELSEN A.L., DEBOSZ K. \& SCHIERUP H.H. (1998), “Extensive grassland systems: Nmineralization, productivity and biodiversity”, Grassland Science in Europe, 3, pp. 315-318.

PRIMDAHL J. (1999), “Agricultural landscapes as places of production and for living in owner's versus producer's decision-making and the implications for planning", Landscape and urban Planning, 46, 1-3, pp. 143-150.

PRIMDAHL J., PECO B., SCHRAMEK J., ANDERSEN E. \& ONATE J. (2003), “Environmental effects of agri-environmental schemes in Western Europe”, Journal of Environmental management, 67, 2, pp. 129-138.

SøRENSEN, ESBEN MUNK m.fl. (1999), "Analyzing current changes in farm structure in two Danish parishes: Types of farmers and their strategies", Forest and Landscape Research, 1, 5.

TRESS B. (2002), "Farming and the landscape: Structures on organic and conventional farms", in BASTIAN O. \& STEIN HARDT U. (Eds.), Development and perspectives in landscape ecology Conceptions, methods, application, Dordrecht, Kluwer Academic Publishers, pp. 352-361.

TRESS G. (2002), “Tourism and the landscape: A mutual relationship”, in BASTIAN O., STEINHARDT U. (Eds.), Development and perspectives in landscape ecology - Conceptions, methods, application, Dordrecht, Kluwer Academic Publishers, pp. 362-373.

\section{NOTES}

1. Man, Landscape and Biodiversity (1995-2001), ( http://www.forsk.dk/forskpro/menneske/ index.htm, http://www.fsl.dk/boundaries/ http://www.geo.rc.dk/vldb), Changing Landscapes, Land Use - The Farmer as Landscape Manager (1995-2001); (http://www.agrsci.dk/jbs/arlas/), Sustainable land use (1999-2000); (http://www.smp.au.dk/ smp.dk/ProgrammetsCentre/c13/c133/ c133.htm), Changing Landscapes (1997-2000), see http://www.sdu.dk/Hum/ForandLand/English/ Index.htm and The Agrarian Landscape (1998-2003) ( http://www.forsk.dk/shf/publ/eval/ agrarelandskab/ and Man, Landscape and Biodiversity).

\section{ABSTRACTS}

Danish landscape research blossomed during the 1990s thanks to several transdisciplinary research programmes involving several institutions. The main themes of the programmes encompassed landscape change, landscape and biological diversity, nature and landscape management, use and monitoring of the countryside. The values of the Danish landscape pertain mainly to the coastal landscapes. The threats include the industrialization of the agricultural landscapes and, in places, urban sprawl. 
Les travaux de recherche consacrés aux paysages du Danemark ont connu, au cours des années 90, un essor considérable grâce à différents programmes de recherche transdisciplinaire menés au sein de plusieurs institutions et centrés sur l'évolution des paysages, la diversité paysagère et biologique, la gestion de la nature et du paysage, l'affectation et le suivi des campagnes. Les points forts du paysage au Danemark sont les paysages côtiers, tandis que les principales menaces proviennent de l'industrialisation des paysages agricoles et, par endroits, de la croissance urbaine.

\section{INDEX}

Mots-clés: Danemark, recherche interdisciplinaire sur les paysages, paysages agricoles, valeurs paysagères, qualité de la nature

Keywords: Denmark, transdisciplinary landscape research, agricultural landscapes, landscape values, nature quality

\section{AUTHORS}

\section{HENRIK VEJRE}

Danish Centre for Forest, Landscape and Planning, Royal Veterinary and Agricultural University, Denmark, hv@kvl.dk.

\section{JESPER BRANDT}

Department of Geography and International Development Studies, University of Roskilde,

Denmark 